\title{
Prediksi Kebangkrutan Perusahaan Manufaktur Pada Fase New Normal (Studi Kasus Pada Perusahaan Logam Yang Terdaftar Di Bursa Efek Indonesia)
}

\author{
Fensca F. Lahallo ${ }^{*}$, Tagor Manurung ${ }^{2}$ \\ ${ }^{1,2}$ Prodi. Manajemen Universitas Victory Sorong \\ Email: ${ }^{1}$ ekalahallo120@gmail.com*; ${ }^{2}$ tagormanurung24031963@gmail.com
}

\begin{abstract}
Abstrak
Tujuan dilakukannya penelitian ini adalah untuk untuk memprediksi kebangrutan perusahaan manufaktur Pada Fase New Normal (Studi Kasus Pada Perusahaan Logam Yang Terdaftar Di Bursa Efek Indonesia (BEI). Jenis penelitian ini adalah penelitian kuantitatif. Populasi dari penelitian ini adalah seluruh perusahaan logam yang terdaftar di Bursa Efek Indonesia. Adapun kriteria didalam memilih sampel adalah: perusahaan tersebut adalah perusahaan manufaktur pada sub sektor logam yang sudah terdaftar di BEI dan tidak IPO di tahun 2020 serta mengeluarkan laporan keuangan dalam triwulan secara konsisten pada periode 2019-2020. Teknik pengumpulan data menggunakan teknik dokumentasi dan studi kepustakaan.Pengukuran standar atau nilai cutt off dalam memprediksi kebangkrutan dengan metode Altman Z-Score. Hasil penelitian menunjukkan bahwa pada tahun 2019 triwulan I, II, dan III, melalui analisis altman z-score, dari 12 perusahaan pada sub sektor logam, terdapat 6 perusahaan yang memiliki potensi kebangkrutan dan 2 perusahaan berpotensi mengalami kebangkrutan pada triwulan I maupun triwulan II. Demikian juga pada tahun 2020, dari 12 sampel penelitian terdapat 6 perusahaan yang berpotensi bangkrut pada triwulan I, II, dan III serta 3 perusahaan yang berpotensi mengalami kebangkrutan pada triwulan I.
\end{abstract}

Kata kunci: Prediksi Kebangkrutan, Altman Z-Score

\section{Prediction of Manufacturing Company Bankruptcy in the New Normal Phase (Case Study on Metal Companies Listed on the Indonesia Stock Exchange)}

\begin{abstract}
The purpose of this research is to predict the bankruptcy of manufacturing companies in the New Normal Phase (Case Study on Metal Companies Listed on the Indonesia Stock Exchange). This type of research is quantitative research. The population of this study is all metal companies listed on the Stock Exchange. Indonesian Securities. The criteria in selecting the sample are: the company is a manufacturing company in the metal subsector that has been listed on the IDX and did not have an IPO in 2020 and issued quarterly financial reports consistently in the 2019-2020 period. Data collection techniques used documentation techniques and literature study. The standard measurement or cut-off value in predicting bankruptcy using the Altman Z-Score method.The results show that in the first, second, and third quarters of 2019, through the altman z-score analysis, of 12 companies in the metals sub-sector, There are 6 companies that have the potential for growth detention centers and 2 companies have the potential to go bankrupt in the first quarter and second quarter. Likewise, in 2020, from the 12 research samples, there are 6 companies that have the potential to go bankrupt in the first, second, and third quarters and 3 companies that have the potential to go bankrupt in the first quarter.
\end{abstract}

Keywords: Bankruptcy Prediction, Altman Z-Score

\section{PENDAHULUAN}

Pandemi Covid-19 yang mewabah di dunia tidak terkecuali Indonesia tidak hanya memberikan ancaman kepada kesehatan saja akan tetapi juga pada pertumbuhan perekonomian. Dampak penyebaran Virus Corona (Covid-19) belum dapat dihitung secara pasti, namun perlambatan sistem ekonomi sudah terasa, terutama di sektor industri, pariwisata, perdagangan, transportasi dan investasi. Dampak yang ditimbulkan dari merebaknya virus tersebut beragam. Bagi perusahaan 
dibidang pembuatan produk-produk kesehatan, kebersihan, dan produk makanan virus ini memberikan dampak positif dikarenakan omset penjualan perusahaan dalam industri tersebut meningkat, sedangkan dampak negatif dirasakan oleh perusahaan di sektor perbankan sebab banyaknya modal asing yang mencabut investasinya sehingga perbankan mengalami kerugian. Dampak negatif lainnya juga dialami oleh sektor pariwisata, perhotelan dan penerbangan. Di Indonesia sendiri diprediksi akan kehilangan devisa dari sektor pariwisata sebesar US\$ 1.3 miliar akibat dari pandemi covid-19. Untuk sektor perhotelan sendiri hanya mendapatkan omset kurang lebih 20 persen saja padahal jika hari-hari biasa omset dari perhotelan sebesar 70 persen. Bagi sektor penerbangan diprediksi akan kehilangan omset sebesar 207 miliar rupiah, hal tersebut disebabkan oleh banyaknya penerbangan yang dibatalkan dan banyaknya bandara yang di tutup [1].

Perusahaan manufaktur merupakan sebuah badan usaha yang kegiatan utamanya memproses bahan mentah menjadi barang jadi sehingga memiliki nilai jual. Pada masa pandemi covid-19 hingga fase new normal ini menjadi entitas yang mengalami goncangan terberat hingga banyak perusahaan manufaktur yang terancam bangkrut. Hal tersebut dikarenakan kinerja perusahaan mengalami penurunan. Misalnya PT. Semen Indonesia (Persero) Tbk, perusahaan yang bergerak dibidang sub sector semen ini merupakan salah satu perusahaan yang memperoleh dampak negatif dari adanya covid-19. Pandemi covid-19 menyebabkan daya beli masyarakat akan produk PT. Semen Indonesia (Persero) Tbk menjadi tertekan. Hal tersebut dapat mempengaruhi jumlah produksi semen dikarenakan permintaan akan produk berkurang. Pada tahun 2020 laba yang dapat diraup oleh perusahaan ini sebesar Rp. 2,67 triliun jumlah ini lebih besar bila dibandingkan dengan tahun sebelumnya yaitu Rp. 2,37 triliun. Tetapi pada masa covid-19 ini, PT. Semen Indonesia (Persero) Tbk memperoleh kerugian di triwulan I sebesar Rp. 64,17 milliar sedangkan pada triwulan II, perusahaan pun mengalami kerugian yang cukup signifikan yaitu sebesar Rp 137,62 milliar.

Demikian juga pada PT Krakatau Steel (Persero), Tbk adalah salah satu perusahaan yang bergerak dalam bidang sub sektor logam dan sejenisnya dengan banyak anak perusahaan. Perusahaan ini merupakan salah satu perusahaan yang memperoleh dampak negatif dari adanya pandemi covid-19. Hampir semua kegiatan bisnis dari anak perusahaannya mengalami penurunan sehingga membuat laba dari PT Krakatau Steel (Persero), Tbk mengalami penurunan. Hal ini terlihat dari data tahun 2020 triwulan I penghasilan yang didapat oleh perusahaan ini sebesar Rp. 3,74 triliun dengan besar keuntungan bersih Rp. 962,38 milliar. Namun pada masa pandemi ini PT Krakatau Steel (Persero), Tbk hanya memperoleh laba bersih sebesar Rp. 56,milliar pada triwulan II. Jumlah ini menurun bila dibandingkan dengan laba triwulan I pada tahun sebelumnya.

Meski banyak perusahaan yang bertahan di masa pandemi covid-19 hingga fase new normal, tapi banyak pula perusahaan yang gulung tikar. Hal tersebut dikarenakan permintaan akan produk terus menurun, sedangkan pengeluaran yang ditanggung perusahaan semakin besar. Hal tersebut membuat perusahaan mau tidak mau memberhentikan banyak karyawannya [1]. Meski tingkat penjualan produk mengalami penurunan perusahaan masih tetap bertahan. Namun tidak menutup kemungkinan bahwa perusahaan yang semula masih bertahan ini akan terus bertahan hingga masa pandemi berakhir. Seperti yang kita tahu hingga saat ini baik pemerintah maupun WHO masih belum dapat memastikan kapan pandemi ini berakhir.

Ancaman yang paling ditakuti perusahaan adalah kebangkrutan. Bangkrut berarti perusahaan tersebut tidak dapat lagi menjalankan usahanya. Kebangkrutan terjadi karena perusahaan tidak mampu lagi melunasi kewajiban perusahaannya. Agar tidak terjadi kebangkrutan, perusahaan harus lebih dini melakukan analisis. Dengan melakukan analisis ini, sangat bermanfaat bagi perusahaan untuk melakukan pencegahan yang diperlukan. Karena salah satu tolak ukur keberhasilan atau kegagalan suatu perusahaan dapat dilihat dari kinerja keuangan perusahaan tersebut melalui laporan keuangan [2]. Laporan keuangan merupakan salah satu informasi yang sangat penting dalam menilai perkembangan perusahaan, dapat juga digunakan untuk menilai prestasi yang dicapai perusahaan pada saat lampau, sekarang dan rencana pada waktu yang akan datang [3]. Laporan keuangan dapat digunakan oleh perusahaan untuk melakukan analisis kebangkrutan [4]. Faktor penyebab kebangkrutan terbagi menjadi dua faktor yaitu, faktor eksternal (kondisi ekonomi, keadaan politik, dan bencana alam) dan faktor internal (kinerja perusahaan, kebijakan perusahaan, dan budaya perusahaan) [5].

Prediksi kebangkrutan perusahaan dapat dilakukan dengan menggunakan metode perhitungan prediksi kebangkrutan perusahaan seperti metode Altman Z-Score. Metode Altman Z-Score merupakan salah satu metode yang 
diciptakan oleh Edward I. Altman berdasarkan hasil penelitiannya, yang berfungsi untuk mempediksi kebangkrutan pada perusahaan dengan tingkat ketepatan dan keakuratan yang relatif dapat dipercaya [6]. Prediksi kebangkrutan dengan menggunakan Altman zscore memiliki 3 (tiga) kriteria, dimana perusahaan yang memiliki nilai $\mathrm{Z}>2,99$ digolongkan sebagai perusahaan sehat. Sedangkan perusahaan yang memiliki nilai $\mathrm{Z}$ antara 1,81 sampai dengan 2,99 merupakan perusahaan rawan bangkrut (grey area). Kriteria yang ketiga yaitu perusahaan dengan nilai $\mathrm{Z}<$ 1,81 , artinya perusahaan berpotensi mengalami kebangkrutan. Tujuan dilakukannya penelitian ini adalah untuk melakukan prediksi kebangkuran Perusahaan Manufaktur Pada Fase New Normal (Studi Kasus Pada Perusahaan Logam Yang Terdaftar Di Bursa Efek Indonesia (BEI) dapat dilihat perusahaan yang termasuk kedalam kategori perusahaan sehat, grey area, maupun perusahaan berpotensi bangkrut.

\section{METODE}

Metode penelitian yang digunakan dalam penelitian ini adalah metode kuantitatif. Lokasi penelitian ini adalah Perusahaan manufaktur yang terdaftar pada Bursa Efek Indonesia (BEI). Data diperoleh melalui laman www. Idx.ac.id Sumber data yang digunakan dalam penelitian ini adalah sumber data sekunder berupa laporan keuangan publikasi yang terdiri dari laporan neraca dan laporan laba/rugi perusahaan manufaktur periode 2019-2020. Populasi dari penelitian ini adalah perusahaan manufaktur pada sub sektor logam yang terdaftar di Bursa Efek. Sampel adalah bagian dari jumlah dan karekteristik yang dimiliki oleh populasi tersebut. Teknik penentual sampel yang digunakan adalah teknik purposive sampling yaitu teknik penentuan sampel berdasarkan kriteria-kriteria tertentu [7]. Adapun kriteria didalam memilih sampel adalah: perusahaan tersebut adalah perusahaan manufaktur pada sub sektor logam yang sudah terdaftar di BEI dan tidak IPO di tahun 2020 serta mengeluarkan laporan keuangan dalam triwulan secara konsisten pada periode 2019 - 2020. Teknik pengumpulan data yang digunakan adalah dokumentasi dan studi kepustakaan. Teknik anaisis data yang digunakan adalah deskripsi kuantitatif. Pengukuran standar atau nilai cutt off dalam memprediksi kebangkrutan dengan metode Altman Z-Score original yaitu sebagai berikut :

$Z=0,717\left(X_{1}\right)+0,847\left(X_{2}\right)+3,107\left(X_{3}\right)+0,420\left(X_{4}\right)+0,998\left(X_{5}\right)$

Adapun nilai cut off yang digunakan adalah:
$\mathrm{Z}<1,81$
$1,81<Z<2,99$
: Bangkrut
$Z>2,99$
: Grey area (daerah abu-abu)
: Tidak bangkrut

Keterangan :

Working Capital To Total Assets $\left(\mathrm{X}_{1}\right)$

Retained Earning To Total Assets $\left(\mathrm{X}_{2}\right)$

EBIT To Total Assets $\left(\mathrm{X}_{3}\right)$

Book Value of Equity To Book Value Of Debt $\left(\mathrm{X}_{4}\right)$

Sales To Total Assets $\left(\mathrm{X}_{5}\right)$

$\mathrm{Z}=$ Overall Index

\section{HASIL DAN PEMBAHASAN}

Berikut adalah hasil perhitungan nilai $\mathrm{z}$ score perusahaan manufaktur pada sub sektor logam dan sejenisnya yang sudah terdaftar di BEI pada tahun 2019 triwulan 1 - triwulan III sebagai berikut :

Tabel 4.1

Perhitungan Z-Score Perusahaan Manufaktur Sub Sektor Logam dan Sejenisnya Tahun 2019

\begin{tabular}{|c|c|c|c|c|c|c|c|c|c|c|}
\hline No & $\begin{array}{c}\text { Nama } \\
\text { Perussaran }\end{array}$ & & Tahun & $\mathrm{x} 1$ & $x_{2}$ & $\mathrm{x} 3$ & $x 4$ & X5 & Z-Score & Prediksi \\
\hline \multirow{3}{*}{1} & \multirow{3}{*}{\begin{tabular}{|l} 
PT. Alakasa \\
Industrindo Tbk
\end{tabular}} & \multirow[b]{3}{*}{2019} & Triwulan 1 & 0.1126 & 0.0404 & 0.0165 & 0.1138 & 1.0149 & 1.2982 & Bangkrut \\
\hline & & & Triwulan 2 & 0.1430 & 0.0574 & 0.0353 & 0.1536 & 2.3822 & 2.7715 & Rawan Bangkut \\
\hline & & & Triwulan 3 & 0.1150 & 0.0519 & 0.0904 & 0.1016 & 2.3787 & 2.7377 & Rawan Bangkut \\
\hline \multirow{3}{*}{2} & \multirow{3}{*}{$\begin{array}{l}\text { PT. Alumindo } \\
\text { Light Metal } \\
\text { Industry Tbk }\end{array}$} & & Triwulan 1 & -0.0320 & -0.0685 & -0.0722 & 0.0632 & 0.4535 & 0.3440 & Bangkrut \\
\hline & & & Triwulan 2 & -0.0662 & -0.1054 & -0.2025 & 0.0550 & 0.8604 & 0.5413 & Bangkrut \\
\hline & & 2019 & Triwulan 3 & -0.0861 & -0.1207 & -0.2924 & 0.0376 & 1.0333 & 0.5716 & Bangkrut \\
\hline \multirow{3}{*}{3} & \multirow{3}{*}{\begin{tabular}{|} 
PT. Saranacentral \\
Bajatama Tbk
\end{tabular}} & & Triwul & -0.0908 & -0.1495 & 0.0237 & 0.0438 & 0.3298 & 0.1571 & Bangkrut \\
\hline & & & Triwulan 2 & -0.1140 & -0.1863 & -0.0358 & 0.0398 & 0.6064 & 0.3100 & Bangkrut \\
\hline & & 2019 & Triwulan 3 & -0.1244 & -0.2029 & -0.0360 & 0.0400 & 0.9764 & 0.6530 & Bangkrut \\
\hline \multirow{3}{*}{4} & \multirow{3}{*}{$\begin{array}{l}\text { PT.Betonjaya } \\
\text { Manungaal TbK }\end{array}$} & & Triwulan 1 & 0.4775 & 0.6356 & 0.0043 & 2.1431 & 0.1205 & 3.3811 & Tidak Bangkrut \\
\hline & & & Triwulan 2 & 0.4537 & 0.6023 & 0.0061 & 1.5879 & 0.2406 & 2.8906 & Rawan Bangkut \\
\hline & & 2019 & Triwulan 3 & 0.4558 & 0.6018 & 0.0589 & 1.5604 & 0.3605 & 3.0373 & Tidak Bangkrut \\
\hline \multirow{3}{*}{5} & \multirow{3}{*}{\begin{tabular}{|l|} 
PT. Citra Tubindo \\
Tbk
\end{tabular}} & & Triwul & 0.1932 & 0.2573 & 0.0374 & 0.6629 & 0.1991 & 1.3498 & Bangkrut \\
\hline & & & Triwulan 2 & 0.2010 & 0.2637 & 0.0570 & 0.6829 & 0.3668 & 1.5713 & Bangkrut \\
\hline & & 2019 & Triwulan 3 & 0.2062 & 0.2691 & 0.0930 & 0.6877 & 0.5548 & 1.8109 & Rawan Ban \\
\hline \multirow{3}{*}{6} & \multirow{3}{*}{\begin{tabular}{|l} 
PT. Indal \\
Aluminium \\
Industry Tbk
\end{tabular}} & & Triwul & 0.0190 & 0.0680 & 0.0412 & 0.1241 & 0.2009 & 0.4532 & \begin{tabular}{|l|} 
Bangkrut \\
\end{tabular} \\
\hline & & & Triwulan 2 & 0.0230 & 0.0757 & 0.0738 & 0.1356 & 0.4039 & 0.7120 & Bangkrut \\
\hline & & 2019 & Triwulan 3 & 0.0443 & 0.0677 & 0.0914 & 0.1326 & 0.6858 & 1.0218 & Bangkrut \\
\hline \multirow{3}{*}{7} & \multirow{3}{*}{\begin{tabular}{|l|} 
PT. Steel Pipe \\
Industry of \\
Indonesia Tbk
\end{tabular}} & & Triwulan 1 & 0.1160 & 0.0932 & 0.0137 & 0.3507 & 0.1901 & 0.7636 & Bangkrut \\
\hline & & & Triwul & 0.1098 & 0.0937 & 0.0314 & 0.3340 & & & \\
\hline & & 2019 & Triwulan 3 & 0.1115 & 0.1018 & 0.0708 & 0.3440 & 0.5340 & 1.1622 & \begin{tabular}{|l|} 
Bangkrut \\
\end{tabular} \\
\hline \multirow{3}{*}{8} & \multirow{3}{*}{$\begin{array}{l}\text { PT. Krakatau Steel } \\
\text { (Persero) Tbk }\end{array}$} & & Triwulan 1 & -0.1139 & -0.1757 & -0.0594 & 0.3079 & 0.1005 & 0.0594 & Bangkrut \\
\hline & & & Triwulan 2 & -0.1368 & -0.1856 & -0.1158 & 0.2774 & 0.1641 & 0.0033 & Bangkrut \\
\hline & & 2019 & Triwulan 3 & 0.0133 & -0.2039 & -0.1527 & 0.2527 & 0.2446 & 0.1540 & Bangkrut \\
\hline \multirow{3}{*}{9} & \multirow{3}{*}{$\begin{array}{l}\text { PT. Lion Metal } \\
\text { Works Tbk }\end{array}$} & & Triwulan 1 & 0.3879 & 0.5071 & 0.0146 & 0.9390 & 0.1299 & 1.9784 & Rawan Bangkut \\
\hline & & & Triwulan 2 & 0.3992 & 0.5196 & 0.0312 & 1.0162 & 0.2601 & 2.2264 & $\begin{array}{l}\text { Rawan Bangkut } \\
\end{array}$ \\
\hline & & 2019 & Triwulan 3 & 0.3880 & 0.5154 & 0.0579 & $\begin{array}{ll}0.9887 \\
\end{array}$ & 0.3841 & 2.3341 & $\begin{array}{l}\text { Rawan Bangkut } \\
\end{array}$ \\
\hline \multirow{3}{*}{10} & \multirow{3}{*}{$\begin{array}{l}\text { PT. Lionmesh } \\
\text { Prima Tbk }\end{array}$} & & Triwulan 1 & 0.3365 & 0.6494 & -0.0282 & 2.1317 & 0.3080 & 3.3974 & Tidak Bangkrut \\
\hline & & & Triwulan 2 & 0.3296 & 0.6505 & -0.1553 & 2.2246 & 0.5292 & 3.5786 & |Tidak Bangkrut \\
\hline & & 2019 & Triwulan 3 & 0.3005 & 0.6088 & 2.6188 & 1.5939 & 0.8412 & 5.9632 & Tidak Bangkrut \\
\hline \multirow{3}{*}{11} & \multirow{3}{*}{$\begin{array}{l}\text { PT.Pelangi Indah } \\
\text { Canindo Tbk }\end{array}$} & & Triwulan 1 & 0.0865 & 0.1673 & 0.0218 & 0.2341 & 0.2425 & 0.7521 & Bangkrut \\
\hline & & & Triwulan 2 & 0.0946 & 0.1701 & 0.0444 & 0.2354 & 0.4714 & 1.0159 & Bangkrut \\
\hline & & 2019 & Triwulan 3 & 0.0928 & 0.1689 & 0.0754 & 0.2299 & 0.6687 & 1.2357 & Bangkrut \\
\hline \multirow{3}{*}{12} & \multirow{3}{*}{$\begin{array}{l}\text { PT.Tembaga } \\
\text { Mulia Semanan } \\
\text { Tbk }\end{array}$} & & Triwulan 1 & -0.0017 & 0.0340 & 0.0265 & 0.1241 & 0.8349 & 1.0178 & Bangkrut \\
\hline & & & Triwulan 2 & 0.0182 & 0.0412 & 0.0660 & 0.1492 & 1.8110 & 2.0857 & Rawan Bangkut \\
\hline & & $\pi 19$ & Triwulan 3 & 0.0464 & 0.0512 & 0.1055 & 0.1706 & 2.8599 & 3.2336 & Tidak Bangkrut \\
\hline
\end{tabular}

Sumber : Data Diolah, 2021

Berdasarkan tabel diatas dapat dijelaskan sebagai berikut :

Working Capital To Total Assets $\left(\mathrm{X}_{1}\right)$. Berdasarkan hasil perhitungan pada tabel diatas dalam menentukan kemampuan perusahaan dalam menghasilkan modal kerja bersih dari seluruh asset yang dimiliki menunjukkan bahwa dari 12 sampel penelitian, terdapat dua perusahaan yang memiliki nilai rasio ini negatif pada triwulan I, II, dan III tahun 2019 yaitu PT. 
Alumindo Light Metal Industry Tbk dan PT. Saranacentral Bajatama Tbk. Demikian juga pada PT. Kraratau Steel (Persero), Tbk yang memiliki penurunan rasio pada triwulan I dan II, sedangkan PT. Tembaga Mulia Semanan, Tbk memiliki rasio negatif di triwulan I. Perusahaan yang memiliki nilai rasionya negatif dapat diindikasikan bahwa perusahaan tersebut sedang mengalami kesulitan dalam menjamin kewajiban yang segera jatuh tempo.

Retained Earning To Total Assets $\left(\mathrm{X}_{2}\right)$. Dari perhitungan nilai rasio laba ditahan yang menunjukkan terdapat tiga perusahaan yang memiliki nilai rasio yang negatif pada triwulan I, II, dan III tahun 2019 yaitu PT. Alumindo Light Metal Industry Tbk, PT. Saranacentral Bajatama Tbk dan PT. Kraratau Steel (Persero), Tbk. kemampuan ketiga perusahaan ini dianggap lemah dalam menghasilkan laba ditahan dari seluruh asset yang dimiliki.

EBIT To Total Assets $\left(\mathrm{X}_{3}\right)$. EBIT merupakan rasio profitabilitas yang berfungsi untuk mengukur kemampuan suatu perusahaan di dalam menghasilkan laba kotor dari seluruh asset yang dimiliki perusahaan. Dari perhitungan rasio ini menunjukkan bahwa perusahaan PT. Alumindo Light Metal Industry Tbk dan PT. Kraratau Steel (Persero), Tbk memiliki nilai rasio negatif pada triwulan I, II, dan III. PT. Saranacentral Bajatama Tbk memiliki nilai rasio yang negatif pada triwulan II, dan III sedangkan PT. Lionmesh Prima Tbk pada triwulan I dan II. Nilai rasio yang negatif menunjukkan bahwa perusahaan-perusahaan tersebut memiliki kemampuan yang rendah dalam pengelolaan asset guna menghasilkan laba kotornya.

Book Value of Equity To Book Value Of Debt $\left(\mathrm{X}_{4}\right)$. Berdasarkan hasil perhitungan diatas, menunjukkan bahwa nilai pasar ekuitas terhadap total hutang menunjukkan hasil yang fluktuatif dengan nilai rasio yang positif. Hal ini mengindikasikan bahwa perusahaan-perusahaan tersebut memiliki jumlah modal yang lebih besar ketimbang harus memanfaatkan seluruh hutangnya dalam menunjang aktivitas operasional perusahaan serta perusahaan memiliki kemampuan menjamin hutang dari ekuitas/modal yang dimiliki.

Sales To Total Assets ( $\left.\mathrm{X}_{5}\right)$. Rasio ini menunjukkan kemampuan perusahaan dalam pengelolaan seluruh asset guna meningkatkan tingkat pendapatan atau penjualan perusahaan. Berdasarkan hasil perhitungan pada tabel diatas dapat menunjukkan bahwa nilai rasio yang dimiliki perusahaan-perusahaan pada sub sektor logam adalah positif sekalipun nilainya berfluktuasi. Hal ini mengindikasikan bahwa perusahaan-perusahaan tersebut secara efisien telah mengelola asset yang dimiliki guna menghasilkan tingkat pendapatan/penjualan maupun laba yang dimiliki.

Setelah melakukan perhitungan terhadap nilai-nilai rasio diatas, maka selanjutnya yaitu menganalisis tingkat kebangkrutan menggunakan analisis altman z-score dari akumulasi keseluruhan jumlah rasio-rasio diatas. Dimana dari perhitungan tersebut menunjukkan bahwa rata-rata pada triwulan I, II, dan III pada tahun 2019, dari 12 perusahaan pada sub sektor logam, terdapat 6 perusahaan yang memiliki potensi kebangkrutan diantaranya adalah PT. Alumindo Light Metal Industry Tbk, PT. Saranacentral Bajatama Tbk, PT. Indal Aluminium Industry Tbk, PT. Steel Pipe Industry of Indonesia Tbk, PT. Kraratau Steel (Persero), Tbk dan PT.Pelangi Indah Canindo Tbk. Sedangkan PT. Citra Tubindo Tbk berpotensi mengalami kebangkrutan pada triwulan I dan II serta PT.Tembaga Mulia Semanan Tbk berpotensi mengalami kebangkrutan pada triwulan I.

Tabel 4.2

Perhitungan Z-Score Perusahaan Manufaktur Sub Sektor Logam dan Sejenisnya Tahun 2020

\begin{tabular}{|c|c|c|c|c|c|c|c|c|c|c|}
\hline No & Nama Perusahaan & & Tahun & $\mathrm{x}_{1}$ & $x_{2}$ & xз & $\mathrm{x} 4$ & x5 & Z-Score & Prediksi \\
\hline \multirow{3}{*}{1} & \multirow{3}{*}{$\begin{array}{l}\text { PT. Alakasa } \\
\text { Industrindo Tbk }\end{array}$} & \multirow[b]{3}{*}{2020} & Triwulan 1 & 0.0951 & 0.0320 & -0.0042 & 0.0806 & 1.1052 & $\begin{array}{ll}1.3087 \\
\end{array}$ & Bangkrut \\
\hline & & & \begin{tabular}{|l} 
Triwulan 2 \\
\end{tabular} & 0.1373 & 0.0472 & 0.0098 & 0.1185 & 2.5697 & 2.8825 & Rawan Bangkut \\
\hline & & & Triwulan 3 & 0.1295 & 0.0500 & 0.0278 & 0.1105 & 3.5732 & 3.8910 & Tidak Bangkrut \\
\hline \multirow{3}{*}{2} & \multirow{3}{*}{$\begin{array}{l}\text { PT. Alumindo Light } \\
\text { Metal Industry Tbk }\end{array}$} & & \begin{tabular}{|l|} 
Triwulan 1 \\
\end{tabular} & -0.2101 & -0.0436 & 0.1150 & -0.0095 & 0.1310 & -0.0171 & Bangkrut \\
\hline & & & Triwulan 2 & -0.2587 & -0.1366 & -0.2479 & -0.0300 & 0.2903 & \begin{tabular}{|l|l|l|}
-0.3829 \\
\end{tabular} & \begin{tabular}{|l} 
Bangkrut \\
\end{tabular} \\
\hline & & 2020 & \begin{tabular}{|l} 
Triwulan 3 \\
\end{tabular} & -0.2199 & -0.1576 & -0.3372 & -0.0455 & 0.4859 & \begin{tabular}{|l|l|}
-0.2743 \\
\end{tabular} & Bangkrut \\
\hline \multirow{3}{*}{3} & \multirow{3}{*}{\begin{tabular}{|l} 
PT. Saranacentral \\
Bajatama Tbk
\end{tabular}} & & Triwulan 1 & -0.1733 & -0.2560 & -0.3565 & -0.0109 & 0.4028 & \begin{tabular}{|l|l|l|}
-0.3939 \\
\end{tabular} & Bangkrut \\
\hline & & & Triwulan 2 & -0.1026 & $\begin{array}{l}-0.1833 \\
\end{array}$ & -0.0231 & 0.0418 & \begin{tabular}{ll|}
0.7583 \\
\end{tabular} & 0.4911 & Bangkrut \\
\hline & & 2020 & Triwulan 3 & -0.0920 & $\begin{array}{l}-0.1751 \\
\end{array}$ & -0.0025 & 0.0445 & 1.1616 & 0.9365 & Bangkrut \\
\hline \multirow{3}{*}{4} & \multirow{3}{*}{$\begin{array}{l}\text { PT.Betonjaya } \\
\text { Manunggal TbK }\end{array}$} & & Triwulan 1 & 0.4752 & 0.6127 & 0.3367 & 1.5932 & 0.0975 & 3.1153 & Tidak Bangkrut \\
\hline & & & Triwulan 2 & 0.4406 & 0.5778 & 0.0504 & 1.2821 & 0.2155 & 2.5664 & Rawan Bangkut \\
\hline & & 2020 & Triwulan 3 & 0.4664 & 0.6057 & 0.1441 & 1.5378 & 0.3402 & 3.0942 & Tidak Bangkrut \\
\hline \multirow{3}{*}{5} & \multirow{3}{*}{$\begin{array}{l}\text { PT.Citra Tubindo } \\
\text { Tbk }\end{array}$} & & Triwulan 1 & 0.2279 & 0.2781 & 0.0355 & 0.8431 & 0.1676 & 1.5523 & Bangkrut \\
\hline & & & Triwulan 2 & 0.2713 & 0.3149 & 0.0829 & 1.2318 & 0.4602 & 2.3611 & Rawan Bangkut \\
\hline & & 2020 & Triwulan 3 & 0.2993 & 0.3329 & 0.0942 & 1.6586 & 0.7457 & 3.1307 & Tidak Bangkrut \\
\hline \multirow{3}{*}{6} & \multirow{3}{*}{\begin{tabular}{|l|} 
PT. Indal \\
Aluminium Industry \\
Tbk
\end{tabular}} & & Triwulan 1 & 0.0247 & 0.0764 & 0.0156 & 0.1406 & 0.2572 & 0.5145 & Bangkrut \\
\hline & & & Triwulan 2 & 0.0274 & 0.0743 & 0.0287 & 0.1360 & 0.4176 & 0.6840 & Bangkrut \\
\hline & & 2020 & Triwulan 3 & 0.0656 & 0.0626 & 0.0312 & 0.1247 & 0.5603 & 0.8443 & Bangkrut \\
\hline \multirow{3}{*}{7} & \multirow{3}{*}{$\begin{array}{l}\text { PT. Steel Pipe } \\
\text { Industryot } \\
\text { Indonesia Tbk }\end{array}$} & & Triwulan 1 & 0.0956 & 0.1061 & -0.0461 & 0.3782 & 0.1645 & 0.6982 & Bangkrut \\
\hline & & & Triwulan 2 & 0.1044 & 0.1178 & 0.0015 & 0.4063 & 0.2637 & 0.8935 & Bangkrut \\
\hline & & 2020 & Triwulan 3 & 0.1072 & 0.1250 & 0.0290 & 0.4246 & 0.4330 & 1.1188 & Bangkrut \\
\hline \multirow{3}{*}{8} & \multirow{3}{*}{\begin{tabular}{|l} 
PT.Krakatau Steel \\
(Persero) Tbk.
\end{tabular}} & & Triwulan 1 & $-0.0521]$ & -0.6129 & 0.0973 & 0.0307 & 0.1060 & \begin{tabular}{|l|l} 
& 0.4310 \\
\end{tabular} & Bangkrut \\
\hline & & & Triwulan 2 & -0.0402 & $\begin{array}{l}-0.5877 \\
\end{array}$ & 0.0224 & 0.0694 & 0.1660 & $\begin{array}{r}-0.3702 \\
\end{array}$ & Bangkrut \\
\hline & & 2020 & Triwulan3 & -0.1175 & -0.5843 & 0.0114 & 0.0617 & 0.2909 & -0.3378 & Bangkrut \\
\hline \multirow{3}{*}{9} & \multirow{3}{*}{\begin{tabular}{|l} 
PT. Lion Metal \\
Works Tbk
\end{tabular}} & & Triwulan 1 & 0.3913 & 0.5062 & 0.0778 & 0.9300 & 0.1122 & 2.0174 & Rawan Bangkut \\
\hline & & & Triwulan 2 & 0.3863 & 0.5034 & -0.0153 & 0.9298 & 0.2078 & 2.0121 & Rawan Bangkut \\
\hline & & 2020 & Triwulan 3 & 0.3953 & 0.5145 & 0.0124 & 0.9918 & 0.3219 & 2.2357 & Rawan Bangkut \\
\hline \multirow{3}{*}{10} & \multirow{3}{*}{$\begin{array}{l}\text { PT. Lionmesh } \\
\text { Prima Tbk }\end{array}$} & & Triwulan 1 & 0.2996 & 0.6127 & 0.0082 & 1.6796 & 0.2007 & 2.8008 & Rawan Bangkut \\
\hline & & & Triwulan 2 & 0.3003 & 0.6198 & -0.0723 & 1.8121 & 0.3961 & 3.0559 & Tidak Bangkrut \\
\hline & & 2020 & Triwulan 3 & 0.2880 & 0.6069 & -0.1338 & 1.6503 & 0.6705 & 3.0819 & Tidak Bangkrut \\
\hline \multirow{3}{*}{11} & \multirow{3}{*}{$\begin{array}{l}\text { PT.Pelangi indah } \\
\text { Canindo Tbk }\end{array}$} & & Triwulan 1 & -0.1174 & 0.1270 & 0.0086 & 0.1574 & 0.1087 & 0.2844 & Bangkrut \\
\hline & & & Triwulan 2 & -0.1681 & 0.0710 & -0.0727 & 0.1107 & 0.1591 & 0.1001 & Bangkrut \\
\hline & & 2020 & Triwulan 3 & -0.1777 & 0.0604 & -0.1086 & 0.1028 & 0.2217 & 0.0987 & Bangkrut \\
\hline \multirow{3}{*}{12} & & & Triwulan 1 & 0.0604 & 0.0735 & 0.0127 & 0.2264 & 0.9682 & 1.3410 & Bangkrut \\
\hline & Semanan Tbk & & Triwulan 2 & 0.0948 & 0.0894 & 0.0732 & 0.2877 & 1.7081 & 2.2531 & Rawan Bangkut \\
\hline & & 2020 & Triwulan 3 & 0.1155 & 0.0859 & 0.0629 & 0.2765 & 2.4936 & 3.0344 & Tidak Bangkrut \\
\hline
\end{tabular}

Sumber : Data Diolah, 2021

Berdasarkan tabel diatas dapat dijelaskan sebagai berikut :

Working Capital To Total Assets ( $\left.\mathrm{X}_{1}\right)$. Berdasrkan perhitungan modal bersih dari seluruh asset yang dimiliki menunjukkan bahwa terdapat beberapa perusahaan yang memiliki nilai rasionya negatif yaitu PT. Alumindo Light Metal Industry Tbk, PT. Saranacentral Bajatama Tbk, PT. Kraratau Steel (Persero), Tbk dan 
PT.Pelangi Indah Canindo Tbk. Perusahaan yang memiliki nilai rasio negatif diindikasikan memiliki kesulitan dalam menjamin kewajiban yang segera jatuh tempo.

Retained Earning To Total Assets $\left(\mathrm{X}_{2}\right)$. Berdasarkan hasil perhitungan pada tabel diatas menunjukkan bahwa PT. Alumindo Light Metal Industry Tbk, PT. Saranacentral Bajatama Tbk dan PT. Kraratau Steel (Persero), Tbk memiliki nilai rasio yang negatif artinya perusahaan tersebut dianggap memiliki kemmapuan yang lemah dalam menghasilkan laba ditahan dari seluruh asset yang dimiliki.

EBIT To Total Assets $\left(\mathrm{X}_{3}\right)$. Berdasarkan perhitungan rasio ini pada tahun 2020 triwulan I, II, dan III menunjukkan bahwa PT. Alaska Industrindo, Tbk memiliki nilai rasio negatif pada triwulan I, PT. Alumindo Light Metal Industry Tbk, PT. Lionmesh Prima, Tbk, PT. Pelangi Indah Canindo Tbk memiliki nilai rasio negatif pada triwulan II \& III, serta PT. Saranacentral Bajatama Tbk memiliki rasio negatif pada triwulan I, II, \& III. Perusahaan perusahaan yang memiliki nilai rasio negatif dapat diindikasikan bahwa perusahaan tersebut memiliki kemampuan yang lemah dalam mengelola asetnya guna menghasilkan laba sebelum pajak.

Book Value of Equity To Book Value Of Debt $\left(\mathrm{X}_{4}\right)$. Berdasarkan hasil perhitungan rasio ini menunjukkan bahwa perusahaan dengan nilai rasio yang negatif adalah PT. Alumindo Light Metal Industry Tbk pada triwulan I, II, \& III, sedangkan PT. Saranacentral Bajatama Tbk memiliki nilai negative pada triwulan I. Hal ini menunjukkan bahwa perusahaan tersebut tidak memiliki kemampuan yang baik dalam menunjang utang jangka panjang dan pendek dengan menggunakan ekuitas perusahaan.

Sales To Total Assets $\left(\mathrm{X}_{5}\right)$. Hasil perhitungan diatas menunjukkan bahwa perusahaan yang terdaftar pada sub sektor logam memiliki nilai rasio yang positif artinya semua perusahaan tersebut memiliki kemampuan yang baik dalam mengelola asset guna menghasilkan tingkat pendapatan atau penjualan.

Dengan demikian dalam menganalisis tingkat kebangkrutan menggunakan analisis altman z-score menunjukkan bahwa rata-rata pada triwulan I, II, dan III pada tahun 2020, dari 12 perusahaan terdapat 6 perusahaan yang memiliki potensi kebangkrutan diantaranya adalah PT. Alumindo Light Metal Industry Tbk, PT. Saranacentral Bajatama Tbk, PT. Indal Aluminium Industry Tbk, PT. Steel Pipe Industry of Indonesia Tbk, PT. Kraratau Steel (Persero), Tbk dan PT.Pelangi Indah Canindo Tbk., sedangkan PT. Alakasa Industrindo Tbk, PT. Citra Tubindo Tbk dan PT.Tembaga
Mulia Semanan Tbk berpotensi mengalami kebangkrutan pada triwulan I.

\section{KESIMPULAN}

Kesimpulan yang dapat diambil adalah sebagai berikut:

Pada tahun 2019 triwulan I, II, dan III menunjukkan bahwa melalui analisis altman zscore, rata-rata pada triwulan I, II, dan III pada dari 12 perusahaan pada sub sektor logam, terdapat 6 perusahaan yang memiliki potensi kebangkrutan dan 2 perusahaan berpotensi mengalami kebangkrutan pada triwulan I maupun triwulan II. Demikian juga pada tahun 2020, dari 12 sampel penelitian terdapat 6 perusahaan yang berpotensi bangkrut pada triwulan I, II, dan III serta 3 perusahaan yang berpotensi mengalami kebangkrutan pada triwulan I.

Jika dibandingkan antara kinerja perusahaan sebelum dan saat fase new normal menunjukkan bahwa rata-rata dari 12 perusahaan pada sub sektor logam mengalami kinerja yang berfluktuasi artinya ada kinerja yang mengalami peningkatan tetapi juga ada perusahaan yang kinerjanya mengalami kemunduran dari segi aspek Working Capital To Total Assets (X1), Retained Earning To Total Assets (X2), EBIT To Total Assets (X3) Book Value of Equity To Book Value Of Debt (X4), dan Sales To Total Assets (X5). Hal ini menunjukkan bahwa dampak dari pandemik covid-19 sangat berpengaruh terhadap kinerja organisasi, bahkan tidak sedikit dari perusahaan-perusahaan tersebut diprediksi mengalami kebangkrutan maupun rawan bangkrut. Tetapi perusahaan tetap menunjukkan upaya dalam mempertahankan eksistensinya dalam persaingan dunia bisnis.

\section{DAFTAR PUSTAKA}

[1] K. D. Setyaningrum, A. D. R. Atahau, and I. M. Sakti, "Analisis Z-Score Dalam Mengukur Kinerja Keuangan Untuk Memprediksi Kebangkrutan Perusahaan Manufaktur Pada Masa Pandemi Covid-19," J. Ris. Akunt. Politala, vol. 3, no. 2, pp. 7487, 2020.

[2] F. F. Lahallo, "Perbandingan Kinerja Keuangan Perusahaan Telekomunikasi Yang Terdaftar Di Bursa Efek Indonesia Periode 2008 - 2017 (Studi Kasus Pada PT. Telekomunikasi Indonesia Tbk, PT. Indosat Tbk, dan PT. XL Axiata Tbk)," Bul. Stud. Ekon., 2019, doi: 10.24843/bse.2018.v23.i02.p09.

[3] A. Dimara, F. F. Lahallo, and T. Manurung, 
6 Jurnal Jendela Ilmu, Vol. 2, No. 1, Juni 2021, hlm. 1-6

"Kinerja Keuangan Pada PT. Telekomunikasi Indonesia (Persero) Tbk. Periode 2012-2016," J. Manaj. DAN BISNIS Indones., vol. 5, no. 1, pp. 43-54, 2019.

[4] Maria Shery Anita, "Analisis Prediksi Kebangkrutan Studi Kasus di Perusahaan Jasa Sub Sektor Retoraan, Hotel, Pariwisata Tahun 2011 - 2015," Universitas Sanata Dharma Yogyakarta, Yogyakarta, 2017.

[5] D. A. Ben, "Analisis Metode Springate (SScore) Sebagai Alat Untuk Memprediksi Kebangkrutan Perusahaan (Studi pada Perusahaan Property dan Real estate yang listing di Bursa Efek Indonesia pada Tahun 2011-2013)," J. Adm. Bisnis, vol. 21, no. 1, 2015.

[6] W. A. Cahyono, "Prediksi kebangkrutan perusahaan pertambangan batubara yang listing di bursa efek indonesia periode 20112012 dengan menggunakan analisis model zscore altman," J. Ilm. Mhs. FEB, vol. 1, no. 2, 2012.

[7] F. F. Lahallo, "Corporate Governance $(\mathrm{Cg})$, Corporate Social Responsibility (Csr) Dan Profitability Pengaruhnya Terhadap Nilai Perusahaan," J. Pitis AKP, vol. 2, no. 1, 2018. 